\title{
Participation in Socialization, Work Profession, Knowledge of Fire Safety Simulation Capabilities According to MFK 7 Snars Accreditation Standards at Bhayangkara Hospital Nganjuk
}

\author{
Prasetyo Umar Hari ${ }^{1}$, Indasah ${ }^{2}$ \\ ${ }^{1}$ Bhayangkara Nganjuk Hospital, \\ Indonesia \\ ${ }^{2}$ Master of Health Postgraduate \\ Program, Institute of Health \\ Science STRADA Indonesia \\ Email: \\ haryumar88@gmail.com
}

Received : October $4^{\text {nd }} 2021$

Accepted : October $15^{\text {rd }} 2021$

Published : November $27^{\text {th }} 2021$

\begin{abstract}
Background: The high number of hospital fire cases demands that all hospitals be able to carry out fire safety. The ability to fire safety must be able to be carried out by all hospital officers, both health and non-health workers (all work professions). The research objective was to analyze the factors that influence the simulation ability of fire safety management according to the MFK 7 SNARS accreditation standard at Bhayangkara Hospital Nganjuk. Subjects and methods: Explanatory survey research design using a cross-sectional approach. The research was conducted from January 16 to February 18, 2021 with a sample of 170 people. Independent variables are participation in socialization, work profession, and knowledge of fire safety. The dependent variable is the ability to simulate fire safety according to the MFK 7 SNARS accreditation standard. The data collection tools used a questionnaire. Data analysis used multiple logistic regression. Results: Participation in socialization $(\mathrm{OR}=2.36$; 95\% CI $=1.04-5.33 ; \mathrm{p}<0.039)$, knowledge of fire safety (OR = 3.18; $95 \% \mathrm{CI}=1.45-6.93 ; \mathrm{p}<0.004)$, significantly increased the ability to simulate fire safety according to MFK 7 SNARS accreditation standards. Work profession $(\mathrm{OR}=1.03 ; 95 \% \mathrm{CI}=$ $0.54-1.96 ; \mathrm{p}<0.934)$ does not affect the ability of fire safety management simulation according to MFK 7 SNARS accreditation standards which is statistically significant. Conclusion: Participation in socialization and knowledge about fire safety increases the ability to simulate fire safety according to MFK 7 SNARS Accreditation standards.
\end{abstract}

Keywords: Fire safety, knowledge, simulation skills, socialization participation, work profession

Copyright (C) 2021 IIK STRADA Indonesia All right reserved.

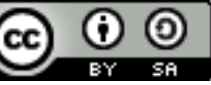

This is an open-acces article distributed under the terms of the Creative Commons AttributionShareAlike 4.0 International License.

\section{INTRODUCTION}

The high number of hospital fire cases demands that all hospitals be able to carry out fire safety. The ability to fire safety must be able to be carried out by all hospital officers, both health and non-health workers or all work professions (Pribadi, 2019). In the MFK 7 standard assessment of SNARS accreditation, the hospital must have a fire protection program that ensures that all hospital residents are safe from the dangers of fire, smoke, or other non-fire emergencies. 
Fire safety operational procedures are procedures for carrying out work from beginning to end which are preceded by a risk assessment of the work which includes the safety and health of related workers (Kurniawati, 2013). Likewise with operational procedures for fire management which aim to prevent and control fires in a building.

Researchers chose Bhayangkara Hospital Nganjuk to be the research site due to fire control at the Bhayangkara Hospital Nganjuk according to PMK RI No. 66 of 2016, there are only light fire extinguishers (APAR), evacuation routes, emergency exits, emergency stairs, safe gathering points, formation of fire prevention teams, training and fire safety socialization. Meanwhile, there is no smoke and fire detection, fire alarm system, automatic water sprinkler, smoke control and manual hydrant. But it is hoped that fire safety can still be carried out by all officers, both health workers and non-health workers at the Bhayangkara Nganjuk hospital on an on going basis. The research objective was to analyze the factors that influence the simulation ability of fire safety management according to the MFK 7 SNARS accreditation standard at Bhayangkara Hospital Nganjuk.

\section{MATERIALS AND METHODS}

\section{Research Design}

This research is an explanatory survey research using a cross-sectional approach, with a quantitative analytic design. Cross-sectional research is a type of research that emphasizes the time to measure data on the independent and dependent variables only once at the time of the study (Nursalam, 2017).

\section{Population and sample}

The implementation of this research was from 16 to 27 February 2021. The population in the study is a subject (eg human, client) who meets predetermined criteria (Nursalam, 2017). Where the population in this study were all officers of the Bhayangkara Nganjuk Hospital, both health workers and non-health workers, amounting to 294 people. The sample in this study were some of the Bhayangkara Nganjuk hospital staff, both health workers and non-health workers, as many as 170 respondents.

\section{Instrument}

The instrument used in this study was a questionnaire. The data collection instrument in this study was a questionnaire consisting of: a questionnaire to identify the knowledge of research subjects about fire management knowledge consisting of 13 question items with multiple choice answers and a questionnaire to identify and observe the ability to simulate fire safety which consists of 10 question items with a choice of answers that can and cannot. In order to obtain valid and reliable data, the questionnaire needs to be tested for validity and reliability first, this is because there is no standard questionnaire yet (Healer dan Twycross, 2016).

The results of the reliability test on the knowledge variable about fire safety and the ability to simulate fire safety according to the SNARS accreditation MFK 7 standard, it can be seen that cronbach's alpha is higher than the baseline values, namely 0.77 and $0.80>0.60$. These results prove that all statements in the questionnaire of both variables are stated to be consistent and reliable

\section{Research Variables}

The independent variables in this study are participation in socialization, work profession and knowledge. The dependent variable in this study is the ability to simulate fire safety according to the MFK 7 SNARS accreditation standard.

\section{Operational Definition}

Socialization participation is devined as Efforts to follow a social interaction process in which people acquire essential knowledge, attitudes, values and behaviors of fire protection as measured by a questionnaire. Parameters have attended fire fighting training at least once a year, $1=$ have attended socialization at least once a year, $0=$ never attended socialization. 
Work profession is staff in a hospital consisting of health workers (health workers) and non health workers (non health workers) as measured by a questionnaire with category $1=$ health workers (health workers), $0=$ non health workers (non health workers). Knowledge about fire safety is the officer's understanding of information on fire management readiness in the face of emergency response to fire disasters in hospitals as measured by a questionnaire. The knowledge category is good if the answer score from the questionnaire is $\geq 61$. Knowledge is less if the answer score from the questionnaire is $<61$.

The ability to simulate fire safety in accordance with the SNARS accreditation MFK 7 standard is the ability to act on fire safety: fire safety (Use of a Light Fire Extinguisher / APAR), rescue and evacuation of patients, evacuation of documents and evacuation of medical devices as measured by a questionnaire. The parameter is that the staff can demonstrate how to bring the patient to a safe place and demonstrate how to save the patient. Score $1=$ able to simulate fire safety, $0=$ unable to simulate fire safety.

\section{Data Processing}

Data processing is carried out by editing techniques, namely re-checking the instruments that have been filled in, scoring, which is to provide the value of each question item and add it up, data coding is to provide research data code for statistical analysis, data entry is to enter data from the questionnaire into computer data according to statistical data, tabulating is data processing with the aim of creating a table that can provide a statistical overview.

\section{Analisis Data}

Analysis of data used to determine the effect of more than one independent variable with one dependent variable using multivariate analysis, namely multiple logistic regression using. Using multivariate logistic regression analysis, it can be seen which independent variable has the greatest influence on the dependent variable.

\section{RESULT}

The subjects in this study were some of the staff at the Bhayangkara Nganjuk hospital, both health workers and non-health workers. The research subjects were 170 people consisting of 85 health workers and 85 non-health workers. The results showed that in the gender characteristics, 81 subjects were male $(48 \%)$ and 89 female subjects $(52 \%)$.

Table 1. Frequency Distribution of Research Subject Characteristics

\begin{tabular}{|c|c|c|c|}
\hline No & Characteristics of Research Subjects & Total & $\%$ \\
\hline \multirow[t]{4}{*}{1} & Gender & & \\
\hline & Men & 81 & 48 \\
\hline & Woman & 89 & 52 \\
\hline & Total & 170 & 100 \\
\hline \multirow[t]{8}{*}{2} & Education & & \\
\hline & a. SD & 2 & 1,2 \\
\hline & b. SLTP & 5 & 2,9 \\
\hline & c. SMA & 59 & 34,7 \\
\hline & d. DIII & 56 & 32,9 \\
\hline & e. $\mathrm{D} 4 / \mathrm{S} 1$ & 45 & 26,5 \\
\hline & f. $\quad$ S2 & 3 & 1,8 \\
\hline & Total & 170 & 100 \\
\hline \multirow[t]{4}{*}{3} & Profession & & \\
\hline & Health workers & 85 & 50 \\
\hline & Non-health personnel & 85 & 50 \\
\hline & Total & 170 & 100 \\
\hline
\end{tabular}


Table 1 shows that of the 170 respondents, the most gender was female, namely 89 (52\%), and male respondents as many as $81(48 \%)$. Most respondents' education was high school (SMA) as much as $59(34.7 \%)$ respondents and the least elementary education was $2(1.2 \%)$ respondents.

Table 2. Distribution of Frequency of Participation in Socialization

\begin{tabular}{ccc}
\hline Participation in Socialization & Total & $\%$ \\
\hline Not following socialization & 32 & 18,8 \\
Follow socialization & 138 & 81,2 \\
\multicolumn{1}{c}{ Total } & 170 & 100 \\
\hline
\end{tabular}

Table 2 shows that of the 170 respondents, most of the respondents had attended the socialization on fire management, namely as many as $132(81.2 \%)$ respondents.

Table 3. Distribution of Frequency of work profession

\begin{tabular}{|c|c|c|}
\hline Work profession & Jumlah & $\%$ \\
\hline Non-health personnel & 85 & 50 \\
\hline Health workers & 85 & 50 \\
\hline Total & 170 & 100 \\
\hline
\end{tabular}

Table 3 shows that of the total number of respondents half of the respondents are health workers, as many as $85(50 \%)$ of respondents.

Table 4. Frequency Distribution of Knowledge about Fire Safety

\begin{tabular}{lccc}
\hline & Knowledge about Fire Safety & Total & $\%$ \\
\hline Less & & 36 & 21,2 \\
Good & \multirow{2}{*}{ Total } & 134 & 78,8 \\
& & 170 & 100 \\
\hline
\end{tabular}

Table 4 . shows that most of the 170 respondents have good knowledge of fire safety, namely as many as $134(78.8 \%)$ of respondents, while $36(21.2 \%)$ of respondents have less knowledge.

Table 5. Fire Safety Simulation Capability according to MFK Standard 7 SNARS

\section{Accreditation}

\begin{tabular}{|c|c|c|}
\hline $\begin{array}{c}\text { Fire Safety Simulation Capability according to MFK } \\
\text { Standard } 7 \text { SNARS Accreditation }\end{array}$ & Total & $\%$ \\
\hline Not capable & 69 & 40,6 \\
\hline Able & 101 & 59,4 \\
\hline Total & 170 & 100 \\
\hline
\end{tabular}

Table 5 shows that most of the 170 respondents were able to simulate fire safety according to MFK 7 accreditation standards, namely 101 (59.4\%) respondents, while 69 (40.6\%) respondents were unable to simulate fire safety according to MFK standards. 7 SNARS accreditation. 
Participation in Socialization, Work Profession, Knowledge of Fire Safety Simulation.....

Tabel 6. Multiple logistic regression analysis

\begin{tabular}{|c|c|c|c|c|c|}
\hline \multirow[b]{2}{*}{ Variable } & \multirow[b]{2}{*}{ B } & \multirow[b]{2}{*}{ OR } & \multicolumn{2}{|c|}{ CI $95 \%$} & \multirow[b]{2}{*}{$\mathrm{P}$} \\
\hline & & & Lower limit & $\begin{array}{c}\text { Upper } \\
\text { limit }\end{array}$ & \\
\hline Participation in socialization & 0.858 & 2.36 & 1.04 & 5.33 & 0.039 \\
\hline Work profession & 0.027 & 1.03 & 0.54 & 1.96 & 0.934 \\
\hline Knowledge of fire safety & 1.157 & 3.18 & 1.45 & 6.93 & 0.004 \\
\hline $\mathrm{N}$ observations & & 170 & & & \\
\hline
\end{tabular}

The results of multivariate analysis between independent variables on the dependent variable with logistic regression test in table 6 show that the independent variable which is a factor in increasing the ability to simulate fire safety according to the MFK 7 SNARS accreditation standard is socialization participation $(\mathrm{p} .=0.039)$ and knowledge of fire safety $(\mathrm{p}=0.004)$, which was statistically significant. The work profession variable $(\mathrm{p}=0.934)$ was statistically significant and did not increase the ability to simulate fire safety according to the SNARS accreditation MFK 7 standard. The most influential variable from the results of multiple logistic regression analysis is knowledge of fire safety.

Based on the results of the analysis of the multivariate odds ratio, it can be interpreted that hospital staff who participate in the socialization of fire management have the ability to simulate fire safety according to MFK 7 SNARS accreditation standards 2.34 times greater than hospital staff who do not participate in the socialization of fire management. And hospital staff who have good fire safety knowledge have the ability to simulate fire safety according to MFK 7 SNARS accreditation standards 3.18 times greater than hospital staff who have less fire safety knowledge.

\section{DISCUSSION}

\section{Effect of participation in the socialization of fire management training with the ability to} simulate fire safety in accordance with MFK 7 SNARS accreditation standards

As much as $52 \%$ or 88 staff of Bhayangkara Nganjuk hospital who have attended the socialization of fire management training are able to carry out fire safety simulations according to MFK 7 SNARS accreditation standards. So that there is an influence between participating in the socialization of fire management training with the ability to simulate fire safety in accordance with MFK 7 SNARS accreditation standards.

This study supports the research conducted by Pambudi in Fitriyana et al (2016) which states that there are differences in attitudes between employees who received training and employees who did not receive fire emergency response preparedness training. The socialization of fire management training is very important because most buildings have fire protection equipment. If these tools are installed, all staff or occupants of the building or building must be trained so that the participants know how to use a fire extinguisher properly.

The conclusion of the description above is hospital staff who participated in the socialization of fire prevention were 2.36 times more likely to be able to carry out fire safety simulations according to MFK 7 SNARS accreditation standards than hospital staff who did not participate in the socialization

\section{The Effect of work profession with the ability to simulate fire safety according to the SNARS accreditation MFK 7 standard}

The results of the analysis show that there is no influence between the work profession and the ability to simulate fire safety according to the MFK 7 SNARS accreditation standard and it is statistically significant. These results indicate that whatever the profession of hospital staff, both health workers 
and non-health workers, does not affect the staff's ability to simulate fire safety according to the SNARS accreditation MFK 7 standard.

A profession is a job that does require certain skills, namely skills that are based on theoretical knowledge and are in accordance with the rules of behavior (code of ethics). Where the knowledge must be obtained from a process of education and training. So that professionals can guide or provide advice / suggestions or also serve others in their field of expertise.

According to Ministerial Decree No. KEP 186 / MEN / 1999 the requirement to become special personnel for fire management is that one of them is the minimum education level of SMP / SLTP. But apart from that, they also have to take special training in basic or level I fire management techniques, so that they can become special fire fighting personnel. At Bhayangkara Nganjuk Hospital, for fire safety, almost all staff, both health and non-medical personnel, are given fire management training and at Bhayangkara Nganjuk Hospital there is a fire management coordinator schedule. So that all staff must be able to perform fire safety according to MFK 7 SNARS accreditation standards. In one day it is divided into 3 teams, morning, afternoon and evening teams. In one team consisting of 4 people, namely as a fire extinguisher coordinator, patient evacuation coordinator, document evacuation coordinator and medical equipment/asset evacuation coordinator.

\section{The effect of knowledge about fire safety with the ability to simulate fire safety according to the MFK 7 SNARS accreditation standard}

The results showed that there was an influence between knowledge about fire safety and the ability to simulate fire safety according to the SNARS accreditation MFK 7 standard and was statistically significant in the bivariate and multivariate tests. This illustrates that knowledge is information that has been combined with understanding and the capacity to act which is then attached to a person's memory. The average score of respondents' knowledge was 61 with a minimum knowledge score of 31 and a maximum knowledge score of 85. This study shows that most of the hospital staff who were respondents in this study had good knowledge of fire safety, namely as many as 134 people or $78,8 \%$. Good knowledge is a level where a person is able to know, understand, apply, analyze, synthesize and evaluate. Staff knowledge is influenced by various factors including information. The hospital provides information to staff by holding outreach on fire management. This may be a supporting factor for the majority of well-informed respondents (Djafar et al, 2015).

This study supports the research of Supirno (2012), that to improve the fire safety simulation ability of hospital staff, it is necessary to conduct socialization and simulation of fire management training. Knowledge of fire extinguishers, how to use them and training to use fire extinguishers are very important for all staff in the hospital, so that in the event of an emergency situation such as a fire incident, the staff will immediately take action to extinguish a small fire so that it does not spread wider and does not get bigger. .

In line with Bloom's opinion, 1908 (in Notoatmojo, 2007) knowledge is the result of "knowing" and occurs after people sense a certain object. Most of human knowledge is obtained through the eyes (sight) and ears (hearing). Knowledge can also be obtained through education, personal experience and the experience of others, the mass media and the environment. The conclusion from the description above is that hospital staff who have good knowledge of fire safety are 3.18 times more likely to be able to carry out fire safety simulations according to MFK 7 SNARS accreditation standards than hospital staff who have less knowledge of fire safety. 


\section{CONCLUSSION}

Participation in socialization and knowledge about fire safety significantly affects the ability of fire safety management simulation according to MFK 7 SNARS accreditation standards. Work profession does not significantly affect the ability of fire safety management simulation according to the SNARS accreditation MFK 7 standard with a p value of 0.934 which means $>0.05$.

Suggestions that can be given in this research are as follows for the hospital. The hospital conducts fire training for hospital staff on a regular basis every six months, as a form of refresher so that employees always remember the training provided. As for the training materials provided in addition to fire safety, it is necessary to add material on evacuation and basic life support. Fire training is an effort to equip hospital employees with knowledge and skills related to emergencies including fires.

Suggestions for the community. The public should pay attention to the danger of fire and maintain the safety of the hospital building, including not smoking in the hospital environment, because fires often occur, leaving a result or pulling cigarette butts carelessly and not ensuring that the discarded cigarette cuttings have actually died.

Suggestions for further researchers. The research results are expected to be used as a reference for further researchers to add other variables that affect the ability of fire safety management simulation according to the SNARS accreditation MFK 7 standard.

\section{ACKNOWLEDGMENT}

Researchers thanked Bhayangkara Nganjuk Hospital and respondents who had been willing to participate in this study.

\section{CONFLICT OF INTEREST}

Researchers declaire that no conflict of interest in this study.

\section{REFERENCES}

Djafar, M. I., Mantu, F. N., \& Patellongi, I. J. (2015). Pengaruh Penyuluhan tentang Kesiapsiagaan Bencana Banjir Terhadap Pengetahuan dan Siap Kepala Keluarga di Desa Romang Tangaya Kelurahan Tamangapa Kecamatan Manggala Kota Makasar.

Fitriyana, I., Ekawati, E., \& Kurniawan, B. (2016). Faktor-Faktor yang Berhubungan dengan Kesiapsiagaan Tanggap Darurat pada Aviation Security Terhadap Bahaya Kebakaran di Terminal Bandara X. Jurnal Kesehatan Masyarakat (e-Journal), 4(3), 416-424

Healer dan Twycross, A. (2016). Validity and Reliability in Quantitative Studies. Evidence Based Nursing, 18(3): 66-67.

Kurniawati, Dewi. (2013). Keselamatan dan Kesehatan Kerja. PT Aksara Sinergi Media: Cetakan Pertama: Surakarta.

Nursalam. (2017). Metodologi penelitian ilmu keperawatan : pendekatan praktis. ed 4. Jakarta: Salemba Medika.

Pribadi, R. H. (2019). Analisis Kesehatan Dan Keselamatan Kerja Dalam Manajemen Tanggap

Darurat Bencana Di Rumah Sakit Angkatan Laut Dr. Mintohardjo Tahun 2019 (Doctoral dissertation, Universitas Pembangunan Nasional Veteran Jakarta).

Undang-Undang Nomor 36 Tahun 2014. (PDF). Kemenko PMK. Diakses tanggal 1 Februari 2020. 